\title{
Identification of Alternaria spp. as causal agent of dead flower buds disease of pear (Pyrus communis) in the Netherlands and methods for disease control
}

\author{
Marcel Wenneker • Khanh T. K. Pham • \\ Joyce H. C. Woudenberg • Bart P. H. J. Thomma
}

Accepted: 6 August 2019/Published online: 2 September 2019

(C) The Author(s) 2019

\begin{abstract}
The occurrence of dead dormant flower buds is a common phenomenon of economic importance in the major pear production areas of Europe. Thus far, the cause of dead flower buds disease remained unknown. Several causes have been proposed, including insufficient tree chilling, unmet dormancy requirements, incompatibility between scion and cultivar, but also various biotic stress agents such as pathogens and pests. In this study, we tested the relationship between reduction of tree growth and dead flower bud incidences, but found no indication that growth regulation can prevent the occurrence of dead flower buds. It has been proposed that the bacterium Pseudomonas syringae pv. syringae may be the causal agent of dead flower buds of pear. However, although we found the bacterium as epiphyte and even as endophyte on and in flower buds, our findings argue that P. syringae pv. syringae is not the causal agent of dead
\end{abstract}

Electronic supplementary material The online version of this article (https://doi.org/10.1007/s10658-019-01827-7) contains supplementary material, which is available to authorized users.

M. Wenneker $(\bowtie) \cdot$ K. T. K. Pham

Wageningen University and Research, Business Unit Field Crops, P.O. Box 200, 6670 AE Zetten, The Netherlands

e-mail: marcel.wenneker@wur.nl

\section{J. H. C. Woudenberg}

Westerdijk Fungal Biodiversity Institute, P.O. Box 85167, 3508

AD Utrecht, The Netherlands

\section{B. P. H. J. Thomma}

Laboratory of Phytopathology, Wageningen University,

P.O. Box 16, 6700 AA Wageningen, The Netherlands flower buds disease in the Netherlands. In our research, Alternaria spp. were consistently found in diseased flower buds, and strong correlations between dead dormant flower buds and infection rates of flower buds with Alternaria spp. were recorded. The isolated Alternaria species were identified as A. arborescens SC and A. alternata SC. Field experiments for disease control showed that the disease may be controlled by specific fungicide applications. Thus, we propose that dead flower buds of pear in the Netherlands should be regarded as a fungal disease caused by $A$. alternata $\mathrm{SC}$ and potentially also $A$. arborescens SC.

Keywords Alternaria spp. Pseudomonas syringae . Pear flower buds $\cdot$ Control

\section{Introduction}

Dead dormant flower buds of pears (Pyrus communis) are a common phenomenon in pear cultivation in the Netherlands, Belgium and Mediterranean countries, and may cause significant (financial) losses due to low harvests (Deckers and Schoofs 2001; Deckers et al. 2008; Montesinos and Vilardell 1991, 2001; Wenneker et al. 2004, 2006). Similarly, further cases of flower bud abortion and floral primordia necrosis are reported from South America (e.g. Uruguay) and South Africa (Arruda and Camelatto 1999; Verissimo et al. 2004; Yamamoto et al. 2010). The impact varies from reduced numbers of flowers per bud, to buds that are completely killed, and 
can reduce the productivity of pear trees substantially (Deckers and Schoofs 2001).

Flower bud formation of pear is the period from the start of the flowering process with flower induction in spring or summer, until flower expression with anthesis occurring in the following spring. After flower induction, successive physiological steps occur, leading to morphological differentiation when the apex becomes organized into a flower primordium or inflorescence. By leaf fall in autumn all parts of the flowers are present in a large percentage of flower buds, and the development of the tissues starts with the sepals, followed by petals and anthers, to finalize with the ovary. In pear, the lower flowers in the cluster develop first and the apical flower develops last, which also is the order of flowering in spring (Faust et al. 1997; Marafon et al. 2010).

Flower bud break in perennial trees is affected by two temperature-dependent processes: 1) accumulation of chilling temperatures to the level required to break dormancy, and 2) accumulation of heat units required for the buds to bloom and foliate (Naor et al. 2003). Inadequate chilling results in several physiological and anatomical abnormalities, including deformation and abscission of flowers, leading to yield reduction (Stushnoff et al. 1984). In temperate climates, significant damage on deciduous fruit trees are produced in buds, flowers and developing fruits after dormancy due to frosts during bloom, which is typically more destructive than low winter temperatures (Rodrigo 2000). Besides damage to the internal tissue of the flower buds, frost damage allows explosive development of epiphytic bacteria in the buds which results in total decay of these buds (Montesinos and Vilardell 1991).

In Southern Brazil it was observed that, regardless of origin or chilling requirements, different cultivars of Pyrus communis and Pyrus pyrifolia produced aborted flower buds (Nakasu et al. 1995). The pear flower bud abortion occurred during the pre-bloom stage following winter dormancy. The aborted buds had dry protector bracts, and dry and necrotic internal flower primordia.

Nakasu et al. (1995) proposed that fluctuations of high temperatures followed by low temperatures are responsible for flower bud abortion. Nevertheless, the impact (if any) of pathogens on flower bud abortion is completely unknown and an area research that deserves attention (Deckers et al. 2008; Montesinos and Vilardell 2001; Nakasu et al. 1995). The bacterium Pseudomonas syringae pv. syringae is the causal agent of blossom blast of pear, characterized by blast of blossom and leaves, which occurs in periods of cool wet weather during bloom and post-bloom stages (Mansvelt and Hattingh 1986; Qiu et al. 2008; Whitesides and Spotts 1991). In Europe it has been suggested that $P$. syringae pv. syringae could be a causal agent of dead flower buds (Deckers et al. 2008; Montesinos and Vilardell 1991). However, symptoms of blossom blast differ from the symptoms of dead flower buds that are characterized by partial or complete necrosis of flower buds during dormancy or at bud break. This dead flower bud necrosis may affect primordial flowers, leaves and scales, and usually starts at the tip part of the bud and progresses to the base. Depending on disease severity, flowers per cluster may be reduced, buds may produce abnormal flowers, or buds may be completely inactive (Fig. 1). When disease incidence is high, vegetative growth of trees is delayed, and trees may become alternate bearers annually.

It has also been suggested that the occurrence of dead flower buds is related to vigorous tree growth (Deckers et al. 2008). Insufficient reduction of shoot growth eventually causes lack of light within the canopy which may negatively affect flower bud development (Maas 2005). High density pear planting systems with 2500 to 3000 trees per hectare in the Netherlands are maintained by the use of dwarfing rootstocks, like quince MC and quince Adams, and additional growth retarding practices. Since the banned use of chlormequat (CCC) in pear orchards from 2001 onwards, root pruning and incision of tree trunks have become major growth-retarding methods. In addition to the mechanical methods for controlling tree vigour, prohexadione-calcium (Regalis) and ethephon

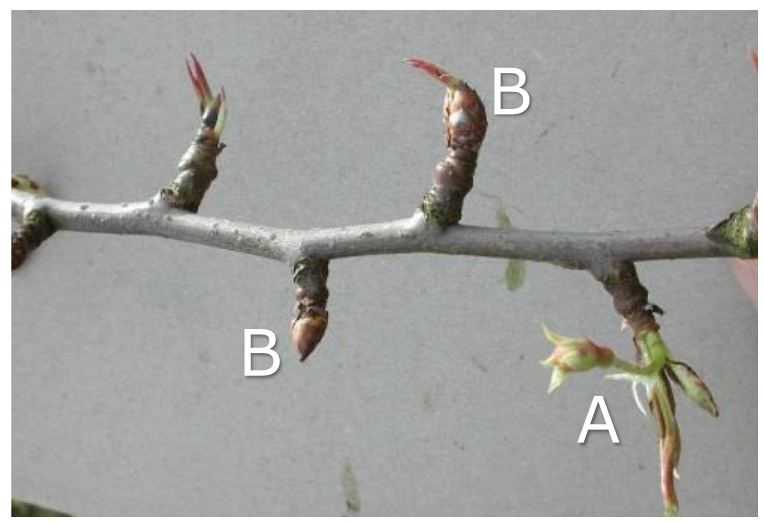

Fig. 1 Symptoms of affected flower buds of pear, the number of flowers per cluster may be reduced (A), or buds may be completely inactive (B) 
(Ethrel-A) were tested as alternative chemical growth regulators (Maas 2005, 2008).

Due to its economic impact, pear growers desire control methods to restrict dead flower buds. Therefore, the aims of this research are (i) to identify the cause of dead flower buds of pears, and (ii) to develop and evaluate possible control strategies.

\section{Materials and methods}

Tree growth regulation and Resistim application

All trials were performed from 2002 to 2005 in an orchard with spindle shaped pear trees (cultivar Conference) on Quince MC rootstock that were planted in 1999 in a single row planting system $(3.5 \mathrm{~m} \times 1.5 \mathrm{~m})$ at the experimental station in Randwijk, the Netherlands.

The following treatments were performed on the same trees in three consecutive years:

1) Ethephon (Luxan ethephon, 48\%): four applications with seven to 10 days intervals with the first application at 2 weeks after bloom. The first application was $250 \mathrm{ml} \mathrm{ha}^{-1}$, the second application $150 \mathrm{ml} \mathrm{ha}^{-1}$, and the third and fourth applications $100 \mathrm{ml} \mathrm{ha}^{-1}$.

2) Prohexadione-calcium (Regalis, 10\%): three applications of $1 \mathrm{~kg} \mathrm{ha}^{-1}$ with tree week intervals and the first application starting at three to five leaf stage.

3) Root pruning: two-sided pruning at $35 \mathrm{~cm}$ from the trunk at the east side of the trees at the end of May and the west side of the trees at the beginning of June.

4) Potassium phosphonate (Resistim, potassium $139 \mathrm{~g} \mathrm{l}^{-1}$; phosphorus $75 \mathrm{~g} \mathrm{l}^{-1}$ ): seven weekly applications of $21 \mathrm{ha}^{-1}$ from the beginning of May onwards.

5) Non-treated control (no growth regulation).

Ethephon, prohexadione-calcium, and potassium phosphonate treatments were carried out as spray applications with a handheld spray gun (manufacturer EMPAS, Veenendaal, the Netherlands) with a $1.2 \mathrm{~mm}$ ceramic hollow cone nozzle at 1.1-1.2 Mpa and a spraying volume of $10001 \mathrm{ha}^{-1}$. The experiment was done in a randomized block design with five replicates. Each replicate consisted of five trees. Observations were made on the middle three trees.
Dead flower bud assessment and statistical analyses

Dead flower bud incidences were assessed in April in the year after the treatments were carried out. Dead flower bud incidence was measured as the percentage of dead flower buds per tree. All flower buds per tree were counted and the disease incidence per tree was calculated from the overall count. In 2004 and 2005 assessments were carried out for different bud types with specific observations for end buds, buds on 1year old twigs, and on $>1$-year old twigs. Mean dead flower bud incidence of all trees for each replicate was used for statistical analysis. The effect of the treatments was determined with ANOVA at a 0.05 probability level.

Assessment of bacterial pathogen presence

Three pear orchards were sampled in 2002 (August 29, September 25, November 1 and 29), and 2003 (February 14, November 12 and December 3) to determine Pseudomonas spp. population levels. A total of 29 bulk samples were taken, each composed of 50 buds from randomly chosen trees, and transported in plastic bags to the laboratory of the National Plant Protection Service (NPPS, Wageningen, The Netherlands). All samples were divided in two sub-samples of 25 buds each, one of which was processed non-sterilized while the other was surface sterilized in $70 \%$ ethanol for $30 \mathrm{~s}$, rinsed three times with distilled water and dried on paper tissue.

The sub-samples were then macerated with mortar and pestle in $5 \mathrm{ml} 0.05 \mathrm{M}$ sterile phosphate buffered saline (PBS), left for $30 \mathrm{~min}$ and again macerated. Suspension aliquots of $100 \mu \mathrm{l}$ were plated onto $3 \mathrm{mod}-$ ified sucrose peptone (MSP) agar plates (Mohan and Schaad 1987) and $20 \mu \mathrm{l}$ was plated onto King's B agar (King et al. 1954) and Levan medium (Lelliott and Stead 1987) and incubated for 4 days at $28^{\circ} \mathrm{C}$. Typical colonies were transferred to nutrient agar (NA) for purification and subsequent identification (Janse 1991).

On November 29 2002, December 20 2002, March 132003 and February 32004 additional bulk samples were collected. In the laboratory these buds were cut in half and examined with a stereo microscope for necrotic flower primordia. Symptomatic buds were processed individually for assessing Pseudomonas spp. presence by macerating in $0.5 \mathrm{ml} 0.05 \mathrm{M}$ sterile PBS and subsequent plating as described above. 
For Pseudomonas inoculation assays, four replicates of 3 twigs (approximately 100 flowers buds in total) were injected into the flower buds with a Pseudomonas syringae pv. syringae (strain PD2873) bacterial suspension $\left(10^{6} \mathrm{CFU} \mathrm{m}{ }^{-1}\right)$. To this end, the needle was carefully introduced into the bud through the 'distal' end until half of its longitudinal axis was reached. Control buds were mock inoculated with sterile water.

Assessment of fungal pathogen presence

Eight commercial pear orchards (cultivar Conference) were sampled in January and February 2004 to determine the presence of fungal pathogens. Random samples of 100 flower buds per orchard were taken. From these samples, 50 buds were cut in half and examined with a stereo microscope for necrotic flower primordia, and 50 buds were individually tested for infection with Alternaria spp. The buds used for determination of infections were surface sterilized by immersing them for $30 \mathrm{~min}$ in $2.5 \%$ formaldehyde-solution (active ingredient $40 \%$ ) and then thoroughly washed in sterile demineralized water to remove sterilizing agent. Subsequently the buds were cut into two pieces, and the flower primordia of each bud were plated onto Potato Dextrose Agar (PDA). Plates were incubated at $20^{\circ} \mathrm{C}$ in the dark for 5-7 days and assessed for the presence of Alternaria spp.

From 2006 to 2013 (except 2010) in 13 commercial pear orchards (cultivar Conference) random samples of 50 flower buds per orchard were individually tested for Alternaria spp. infections in February. In addition, dead flower bud incidences per orchard were determined in April and this was measured as the percentage of dead flower buds per tree. All flower buds of 15 random trees per orchard were assessed.

Identification of the Alternaria species

A total of 63 single spore isolates were used in this study. Isolates were selected from diseased flower buds of different pear cultivars (Conference, 25 isolates; Doyenné du Comice, 10 isolates; Xenia, 10 isolates) and 18 isolates from apple cultivar Golden Delicious with leaf blotch symptoms (Wenneker et al. 2018). Each single spore isolate was grown on potato dextrose agar (PDA; Difco Laboratories Inc.) and incubated for $10-14$ days at $20^{\circ} \mathrm{C}$ in the dark. The isolates were identified to the genus level by morphological characteristics. The identity of the isolates was confirmed by means of multi-locus gene sequencing. To this end, genomic DNA was extracted using the UltraClean ${ }^{\mathrm{TM}}$ Microbial DNA isolation kit (MoBio Laboratories, Carlsbad, CA, USA). Sequences of the ITS region, the endoPG gene and the anonymous region OPA10-2 locus were amplified and sequenced as described by Woudenberg et al. $(2013,2015)$ and subsequently deposited in GenBank.

Pathogenicity trials

\section{Dormant pear flower buds}

Shoots were cut from 1 year-old wood of 'Conference' trees in April, when flower buds were just beginning to swell. Four replicates of 3 twigs (approximately 100 flowers buds in total) were placed in a climate chamber in transparent $300 \mathrm{ml}$ bottles filled with water to which 'white Chrysal' (15 $\left.\mathrm{g} \mathrm{l}^{-1}\right)$ was added. Water was refreshed weekly, and a few millimetres from the basal part of each shoot were cut away every other day. Flower buds were injected with $10 \mu \mathrm{l}$ of an Alternaria alternata spore suspension $\left(10^{5}\right.$ spores $\left.\mathrm{ml}^{-1}\right)$ prepared from 14-day-old culture. The needle was carefully introduced into the bud through the 'distal' end until half of its longitudinal axis was reached. Control buds were mock inoculated in the same way with sterile water. The shoots were incubated at $15^{\circ} \mathrm{C}$ and a 10 -h photoperiod. After inoculation the relative air humidity was maintained at $100 \%$ during the first day by covering the shoots with a plastic bag. Viability of the Alternaria spores was confirmed to be $>90 \%$ by counting the number of germinated spores upon plating of $50 \mu \mathrm{l}$ of the spore suspension for $24 \mathrm{~h}$ at $20^{\circ} \mathrm{C}$ on water agar.

\section{Pathogenicity Alternaria spp. on detached apple and pear leaves}

Ten isolates of the two Alternaria species groups were selected randomly from the set of 63 isolates as described previously; i.e. 3 Alternaria arborescens SC isolates from 'Golden delicious' apple leaves and 3 A. arborescens SC isolates from dormant pear flower buds ( 2 isolates of 'Conference' and of 1 'Doyenné du Comice'), and 4 Alternaria alternata isolates from 'Conference' flower buds. Surface sterilized leaves were inoculated on the abaxial side with $10 \mu \mathrm{l}$ of a suspension of $10^{5}$ conidiospores $\mathrm{ml}^{-1}$, prepared from a 14-day-old PDA culture, after wounding with a needle, 
with four inoculations per leaf. Control leaves were mock inoculated with sterile water. Inoculated leaves were sealed in a plastic box, to maintain the humidity, and incubated in darkness at $20{ }^{\circ} \mathrm{C}$. Pathogenicity was assessed after 3, 5, and 7 days. The experiment was carried out in five replicates.

Fungicide trials

\section{Efficacy of products}

This experiment was performed in a nine-year-old pear orchard with spindle shaped pear trees (cultivar Conference) on Quince MC rootstocks planted in a single row planting system $(3.5 \mathrm{~m} \times 1.5 \mathrm{~m})$ at the experimental station at Randwijk, the Netherlands. The following treatments were performed in twelve weekly spray applications with the first application starting at the end of May and the last application at end of August (shortly before harvest).

1) Thiram (Thiram, 80\%): applications of $2 \mathrm{~kg} \mathrm{ha}^{-1}$.

2) Cyprodinil+fludioxonil (Switch: $37.5 \%$ cyprodinil $+25 \%$ fludioxonil): applications of $0.8 \mathrm{~kg} \mathrm{ha}^{-1}$.

3) Tolylfluanid (Eupareen, 50\%): applications of $2.25 \mathrm{~kg} \mathrm{ha}^{-1}$.

4) Saponin (Yucca schidigera extract, 90\%): applications of $7.51 \mathrm{ha}^{-1}$.

5) Captan (Malvin, 80\%): applications of $2.25 \mathrm{~kg} \mathrm{ha}^{-1}$.

6) Untreated control (no fungicide applications).

The spray applications were carried out with a cross flow sprayer (Homeco Urgent, Dieren, the Netherlands) with Albuz lilac hollow cone nozzles at $5 \mathrm{Mpa}$ and a spray volume of $3201 \mathrm{ha}^{-1}$. The experiment was done in a randomized block design with four replicates. Each replicate consisted of seven trees. Observations were made on the middle five trees. All flower buds per tree were counted and the disease incidence per tree was calculated from the overall count. Mean disease incidence of all trees for each replicate was used for statistical analysis. Effect of treatments was determined with ANOVA at a 0.05 probability level.

\section{Timing of application}

This experiment was carried out in a six-year-old pear orchard located at the experimental station at Randwijk, the Netherlands. The orchard was of spindle shaped pear trees (cultivar Conference) on Quince MC rootstocks. Trees were planted a single row planting system $(3.5 \mathrm{~m} \times 1.5 \mathrm{~m})$. The efficacy of the Alternaria-specific fungicide iprodione (Rovral aquaflow, $50 \%$ ) was tested at a dose rate of $1500 \mathrm{ml}$ per $10001(0.15 \% \mathrm{v} / \mathrm{v})$.

Spray applications were carried out with a handheld spray gun (manufacturer EMPAS, Veenendaal, the Netherlands) with a $1.2 \mathrm{~mm}$ ceramic hollow cone nozzle at 1.1-1.2 Mpa and a spraying volume of $10001 \mathrm{ha}^{-1}$. The experiment was done in a randomized block design with four replicates. Each replicate consisted of 7 trees. Observations were made on the middle five trees.

The experiment consisted of the following treatments:

1) Untreated control (no fungicide applications) (T1).

2) Fourteen spray applications with 2 weeks interval with the first application at end of May until harvest (nine applications), after harvest (two applications) and before bloom the following season (three applications) (T2).

3) Nine spray applications with 2 weeks interval with the first application at end of May and until harvest (T3).

4) Three spray applications with 2 weeks interval with the first application at the end of May (T4).

5) Three spray applications with 2 weeks interval with the first application at the beginning of July (T5).

6) Three spray applications with 2 weeks interval with the first application at the beginning of August (T6).

7) Two spray applications with 2 weeks interval with the first application at the beginning of October (T7).

8) Three spray applications with 2 weeks interval with the first application at the beginning of March of the new growing season (T8).

Before bloom (February) 50 dormant flower buds per treatment (randomly taken over replicates) were individually assessed for infection with Alternaria spp., as described previously. Disease incidence was assessed at the beginning of bloom (April). All flower buds per tree were counted and the disease incidence per tree was calculated from the overall count. Mean disease incidence of all trees for each replicate was used for statistical analysis. Effect of treatments was determined with ANOVA at a 0.05 probability level. 


\section{Results}

Effect of tree growth regulation and potassium phosphonate application on dead dormant flower buds

To investigate to what extent the occurrence of dead flower buds on pear trees in the Netherlands are a physiological disorder, the effects of tree growth regulation on the occurrence of dead dormant flower buds was assessed. The incidence of dead flower buds in the control treatment that did not receive any means of growth regulation was $35 \%, 20 \%$, and $17 \%$ in 2003 , 2004 , and 2005, respectively. No effect of any of the treatments was observed on the incidence of dead flower buds in 2003 (Fig. 2). For ethephon no effect was observed in 2004 and 2005 as well. In contrast, prohexadione-calcium (Regalis) application increased dead flower bud incidences in 2004 and 2005, as did root pruning in 2004. However, overall we did not find any indication that growth regulation can prevent the occurrence of dead flower buds.

Besides growth regulators, we also tested the ability of potassium phosphonate (Resistim), a phosphonate derivate that is based on phosphorous acid that is used in crop protection, to affect dead flower buds incidence. Interestingly, potassium phosphonate application reduced this incidence in 2004. Remarkably, the reduction concerned end buds only and not buds of one-year-old or older twigs (Fig. 3). The fact that potassium phosphonate reduced dead flower buds incidence hinted towards the possible involvement of microbial pathogens in the occurrence of dead flower buds disease.

Assessment of possible bacterial pathogen involvement in the occurrence of dead flower buds disease

It has previously been suggested that Pseudomonas syringae pv. syringae may be a causal agent of dead flower buds (Montesinos and Vilardell 1991; Deckers et al. 2008). The inspection of individual flower buds revealed that approximately $50 \%$ of the buds collected in February 2003 showed visual symptoms of internal necrosis in these three orchards. Analysis of surfacesterilized as well as non-sterilized bud samples revealed that $P$. syringae pv. syringae could not consistently be isolated from the buds. Of the 15 surface sterilized samples that were composed of 25 dead buds each, the bacterium was only found in five samples. Similarly, of

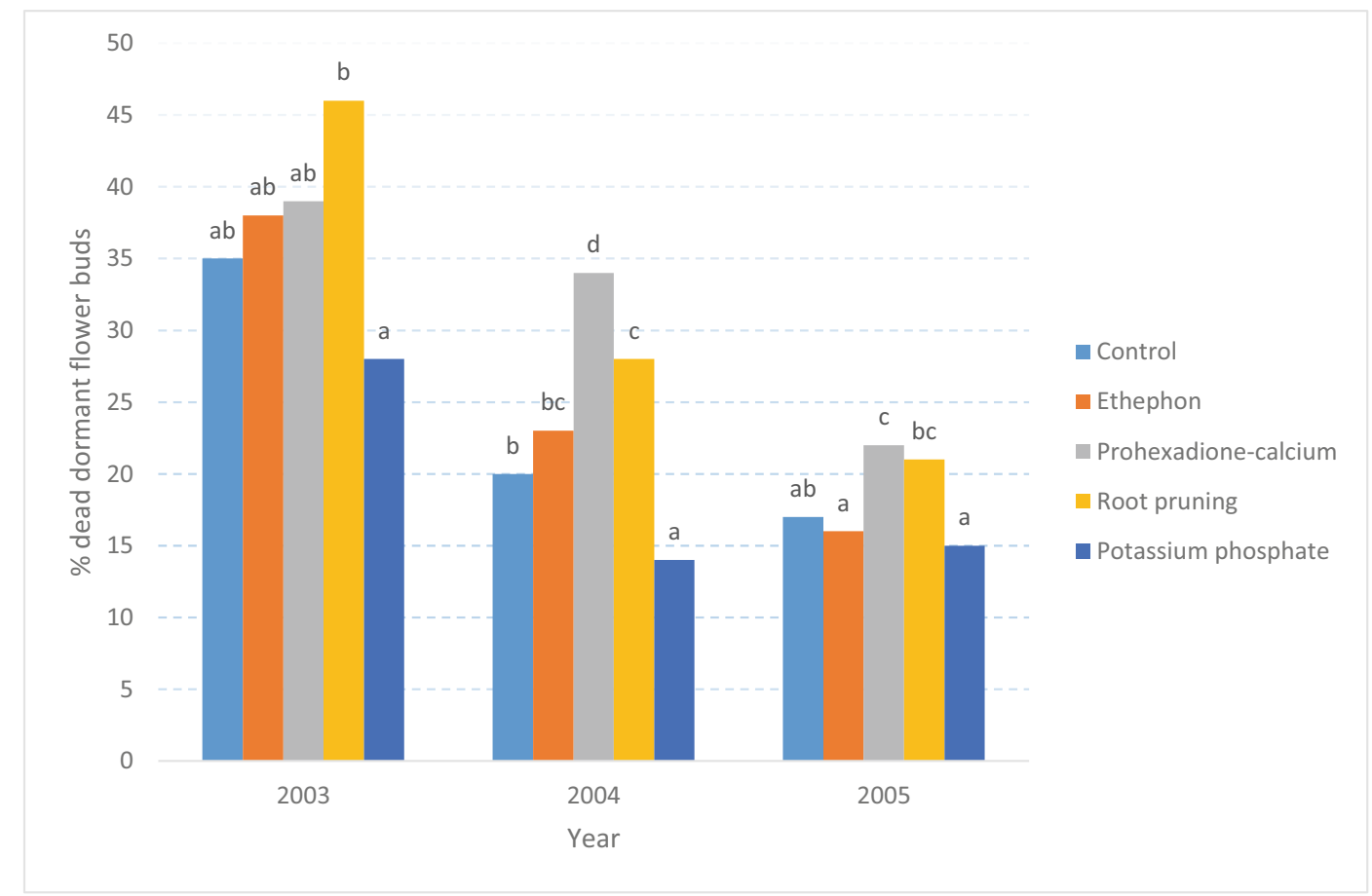

Fig. 2 Effect of growth regulation and potassium phosphate (Resistim) treatments on dead dormant flower buds. Different letter labels indicate significant differences $(P=0.05)$ 


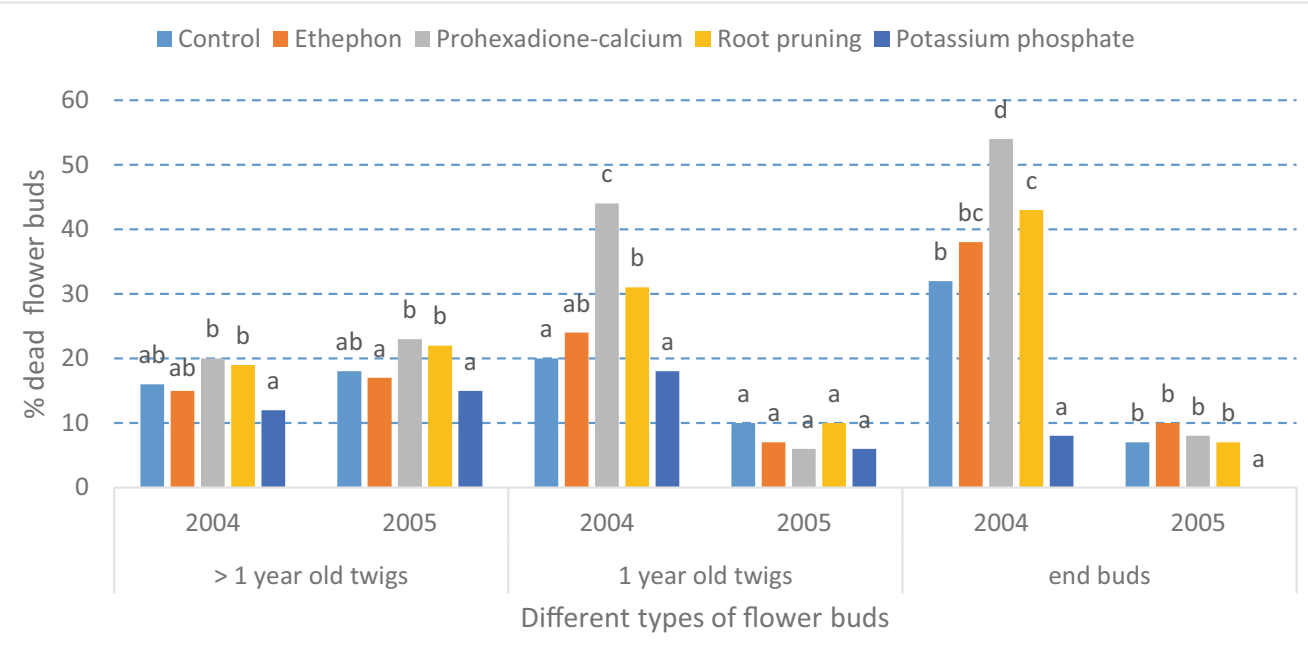

Fig. 3 Effect of growth regulation and potassium phosphate (Resistim) application on death of specific flower buds in 2004 and 2005. Different letter labels indicate significant differences $(P=0.05)$

the 12 surface-sterilized samples of 25 dead buds, the bacterium was found in six samples. Moreover, in the samples where the bacterium was found, only low densities were monitored of maximum 5 colony forming units in $100 \mu \mathrm{L}$ bud extract.

Besides random bud samples, symptomatic dormant 'Conference' buds were collected from another orchard that showed severe symptoms of dead flower buds disease with $>50 \%$ affected flower buds and individually analyzed in 2003, 2004, and 2006. Only six of 41 buds $(15 \%)$ in 2003, one of 15 buds (7\%) in 2004, and three of 20 buds (15\%) in 2006 carried P. syringae pv. syringae.

Despite the lack of correlation between $P$. syringae pv. syringae colonization and dead flower buds occurrence, an inoculation experiment was carried out in the laboratory on cut shoots with dormant 'Conference' pear flower buds. Although the inoculation of dormant flower buds with $P$. syringae pv. syringae resulted in significantly more dead flower buds than among noninoculated buds, mock-inoculation with buffer resulted in similarly increased numbers of dead flower buds.

Collectively, our findings suggest that $P$. syringae pv. syringae may be present as an epiphyte and even as an endophyte on and in flower buds, but is not the causal agent of dead flower buds disease.

Assessment of possible fungal pathogen involvement in the occurrence of dead flower buds disease

For a number of years, dormant pear flower buds from various orchards were assessed for the presence of disease symptoms (Fig. 4). In general, from August to
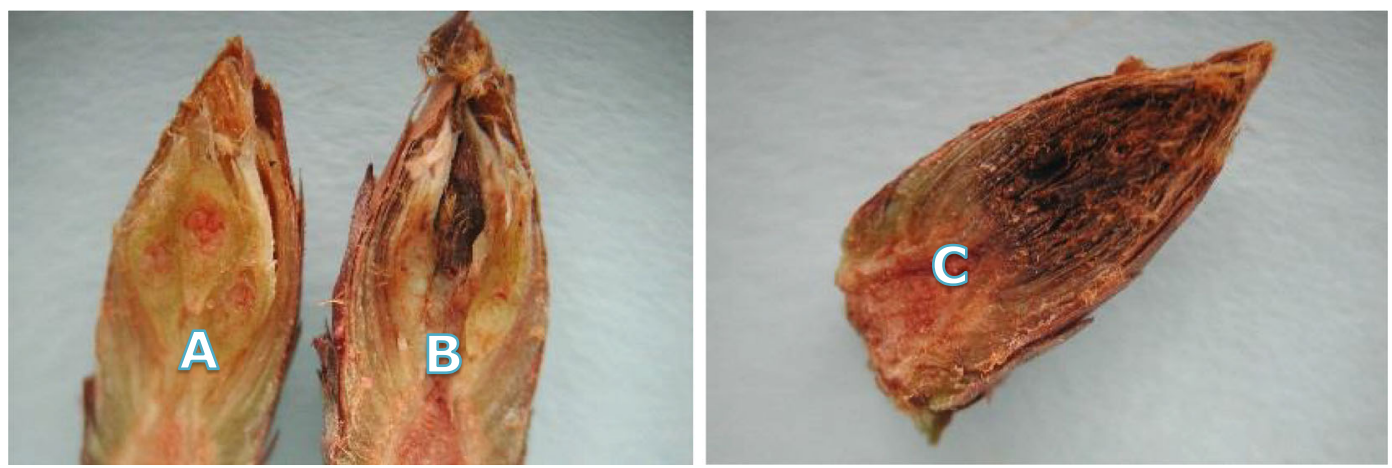

Fig. 4 Typical symptoms of dead flower buds disease. Cross section through a healthy flower bud (A); a diseased flower bud with complete necrosis of the apical flower (B); and total decay of a dormant flower bud (C) 
November no visual disease symptoms were observed. However, from November onwards the first necrotic spots were observed on the flower primordia as well as necrosis of individual flower primordia. Subsequently, the symptoms progressed and often resulted in total decay of the dormant flower bud (Fig. 4C). However, in other cases necrosis of only the apical flower was observed (Fig. 4B).

An extended assessment for the occurrence of internal symptoms, comprising necrotic spots and dead flower primordia, in dormant flower buds collected in eight commercial 'Conference' orchards was carried out in February 2004. The incidence of affected dormant flower buds ranged from 2 to $50 \%$ between the orchards. Isolations from symptomatic flower primordia generally yielded only one type of fungus. All isolates produced fast-growing colonies of irregular shape, tan brown to black and felty. Sporulation patterns showed long conidiophores with extensive terminal branching. Conidia were ovoid with a tapering apical beak and a size range of $10-30 \times 5-10 \mu \mathrm{m}$, with one to five septa. The isolated fungi were morphologically identical to small spored Alternaria spp. (Simmons 2007). Importantly, small spored Alternaria spp. cannot be classified further based on morphological characteristics (Woudenberg et al. 2015).

The Alternaria spp. was found in almost all diseased flower buds, but also frequently occurred in asymptomatic flower buds (Table 1). The infection rate of flower buds (i.e. symptomatic and asymptomatic flower buds) with Alternaria spp. ranged from 10 to $85 \%$. However, the occurrence of visible flower bud symptoms and infection with Alternaria spp. correlated highly in these orchards (Fig. 5).

Table 1 Percentage of symptomatic and a-symptomatic dormant flower buds (assessed in January/February) infected with Alternaria spp.. Mean value of 500 buds (i.e. 50 buds of 10 commercial orchards were assessed annually 2007-2009)

\begin{tabular}{|c|c|c|c|c|}
\hline & \multicolumn{2}{|c|}{ Symptomatic buds } & \multicolumn{2}{|c|}{ A-symptomatic buds } \\
\hline & $\begin{array}{l}\text { No. of } \\
\text { buds }\end{array}$ & $\begin{array}{l}\% \text { infected with } \\
\text { Alternaria spp. }\end{array}$ & $\begin{array}{l}\text { No. of } \\
\text { buds }\end{array}$ & $\begin{array}{l}\% \text { infected with } \\
\text { Alternaria spp. }\end{array}$ \\
\hline 2007 & 240 & 95 & 260 & 70 \\
\hline 2008 & 91 & 88 & 409 & 30 \\
\hline 2009 & 109 & 87 & 381 & 29 \\
\hline
\end{tabular}

Further implication of Alternaria spp. in dead flower buds disease of pear

Yearly assessments were carried out between 2006 and 2013 (except for 2010) in commercial 'Conference' pear orchards to evaluate incidences of dead flower buds due to Alternaria spp. The infection levels of dormant flower buds with Alternaria spp. varied considerably between years and orchards. Very high Alternaria infection levels were observed in 2006 and 2007, when $>60 \%$ of the dormant flower buds were infected. In 2007 two orchards even showed infections in $100 \%$ of the dormant flowers buds. In 2008, 2009 and 2012 a wide range of dormant flower bud infections by Alternaria spp. were recorded, varying from 5 to $90 \%$ between the orchards. In contrast, in 2011 and 2013 overall relatively low infection levels were observed. In the years 2007, 2008, 2009 and 2012 a high correlation was found between infection with Alternaria spp. and the occurrence of dead flower buds. Nevertheless, in 2006, 2011 and 2013 low correlations were found (Supplemental material Fig. S1).

Between 2006 and 2011 it was determined that 33 to $55 \%$ of the Alternaria infections resulted into dead flower buds, whereas in 2012 all infections led to dead buds. In contrast, in 2013 only on average $13 \%$ of the infections resulted in dead flower buds (Table 2). In conclusion, the Alternaria infection rates vary between years and orchards. Likewise, also the severity of symptom expression varies considerably, with a dead flower bud as the most severe symptom.

Identification of the Alternaria species found in dead flower buds of pear

Five mono-spore isolates of the Alternaria spp. were prepared, sent to the Westerdijk Fungal Biodiversity Institute (The Netherlands), and identified as belonging to the Alternaria alternata species complex (SC) in 2004. We subsequently characterized a collection of 45 mono-spore Alternaria spp. isolates that were collected from symptomatic pear flower buds of different pear cultivars (Conference, Doyenné du Comice, Xenia; 25 , 10 , and 10 isolates, respectively). All isolates were morphologically identical to small spored Alternaria spp. (Simmons 2007). To determine the species level, sequences of the ITS region, the endoPG gene and the anonymous region $O P A 10-2$ locus were amplified and sequenced as described in Woudenberg et al. (2013, 


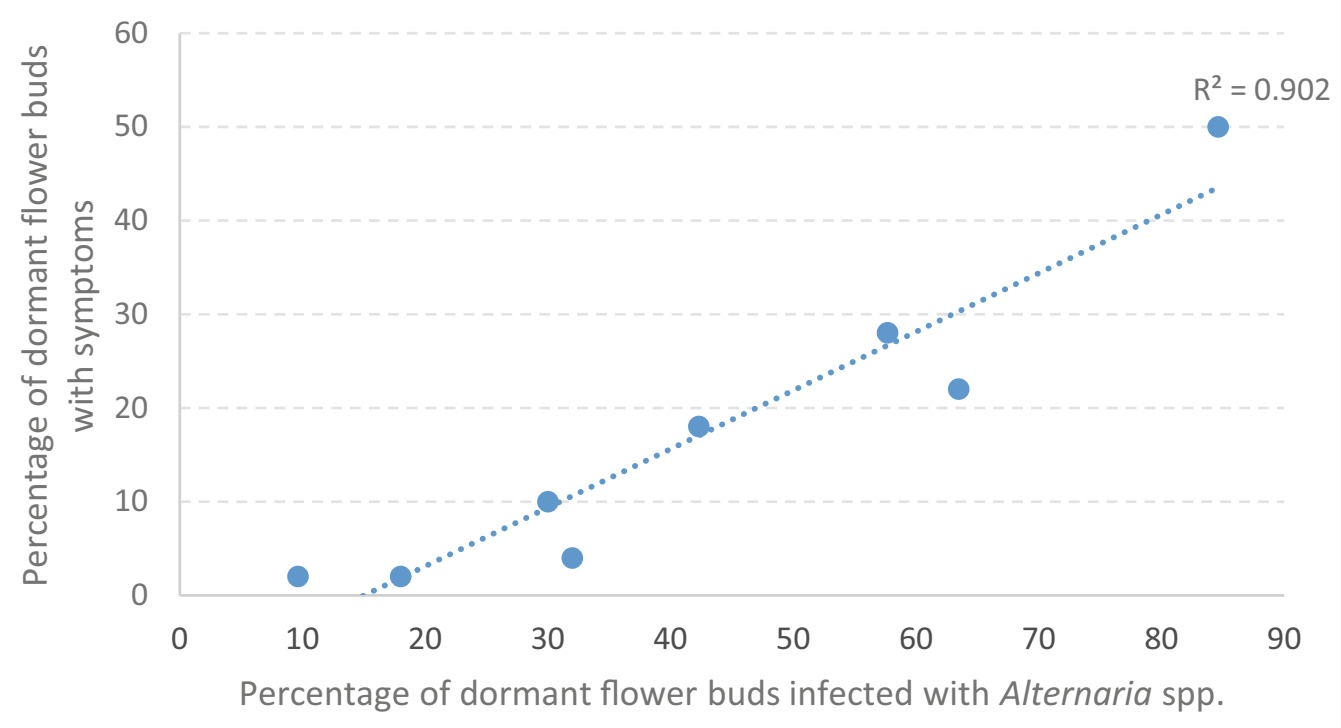

Fig. 5 Relation between symptoms and infection of Alternaria spp. in dormant flower buds of commercial orchards in 2004 . Each dot represents a commercial orchard

2015) and deposited under GenBank accession numbers for the A. arborescens species complex (34 isolates) MH975070-MH975103 (ITS), MH975104-MH975137 (endoPG), and MH975104-MH975137 (OPA10-2), and for the A. alternata species complex (11 isolates) MH975172-MH975182 (ITS), MH975194-MH975204 (endoPG), and MH975183-MH975193 (OPA10-2). MegaBLAST analysis revealed that our ITS, endoPG and $O P A 10-2$ sequences matched with $>99 \%-100 \%$ identity either to the $A$. arborescens species complex

Table 2 Average percentage of infected flower buds, percentage of dead flower buds, and percentage of infections that resulted into dead flower buds in commercial 'Conference' orchards

\begin{tabular}{llll}
\hline Year & $\begin{array}{l}\text { Average \% infected } \\
\text { flower buds }\end{array}$ & $\begin{array}{l}\text { \% of dead } \\
\text { flower buds }\end{array}$ & $\begin{array}{l}\text { \% of infections } \\
\text { resulting into } \\
\text { dead flower buds }\end{array}$ \\
\hline 2006 & 78 & 33 & 42 \\
2007 & 84 & 46 & 55 \\
2008 & 39 & 21 & 55 \\
2009 & 43 & 14 & 33 \\
2011 & 27 & 10 & 37 \\
2012 & 43 & 45 & 101 \\
2013 & 21 & 3 & 13
\end{tabular}

see supplemental Fig. S1 for the results of the individual orchards

a average of all flower buds of the assessed commercial orchards
(34 isolates $=75.5 \%)$ and the A. alternata species complex (11 isolates $=24.5 \%)$ in GenBank (A. arborescens: AF347033 \& KP124400 (ITS), AY295028 \& KP124104 (endoPG) and KP124712 \& KP124714 (OPA10-2); A. alternata: KP124298 \& KP124305 (ITS), AY295020 \& KP124005 (endoPG) and JQ800620 \& KP124613 (OPA10-2)).

Pathogenicity trial

To confirm pathogenicity of isolates that were obtained, an inoculation experiment on dormant 'Conference' pear flower buds was carried out on cut shoots in the laboratory with a single spore isolate of A. alternata SC from a symptomatic pear bud. Whereas an increase in the number of dead buds was observed upon mockinoculation with buffer, presumably due to damage by the needle, inoculation with $A$. alternata resulted in sharply increased dead flower bud incidence. The fungus was successfully re-isolated from symptomatic buds and the identity was confirmed by morphological characteristics. These data suggest that A. alternata SC is capable of causing dead flower buds.

We further generated a collection of 18 single spore isolates from apple leaves ('Golden Delicious') with Alternaria leaf blotch symptoms (Wenneker et al. 2018) and determined the species based on ITS, 
endoPG and the OPA10-2 sequences. Also in this case, we found that the isolates belonged to the A. arborescens (13 isolates) or the A. alternata species complex (five isolates). Next, a pathogenicity assay on detached apple and pear leaves was carried out, assuming that this would indicate the possibility of A. arborescens and/or the A. alternata species complex to cause necrotic flower bud primordia in pear flowers and leaf blotch on apple. To this end, the pathogenicity of $6 \mathrm{~A}$. arborescens $\mathrm{SC}$ isolates (three isolates from apple leaf blotch and three isolates from diseased pear buds) and 4 A. alternata SC isolates (from pear) was tested on wounded apple and pear leaves in a cross-inoculation experiment. Symptoms appeared within 7 days on all of the inoculated apple and pear leaves, while mock-inoculated controls remained symptomless. Fungal colonies isolated from the lesions cultured on PDA morphologically resembled the original isolates and the identity of the reisolations was confirmed as A. arborescens $\mathrm{SC}$ or A. alternata $\mathrm{SC}$ by sequencing. This finding indicates that both Alternaria species are cross-pathogenic between apple and pear.

Fungicide trials

Dead dormant flower bud incidences ranged from 27 to $79 \%$ between the different treatments (Fig. 6). The lowest dead flower bud incidences were observed for the cyprodinil + fludioxonil (Switch) applications. Interestingly, no effect on dead flowers buds incidence was observed upon twelve applications of thiram, saponin or tolylfluanid, whereas captan applications even increased of dead flower buds numbers.

In addition, we tested the timing of application of the Alternaria specific fungicide iprodione (Rovral) by spraying in distinct periods, with different numbers of sprayings. Dead dormant flower bud incidences ranged from 14 to $48 \%$ in this experiment (Fig. 7). The lowest dead flower bud incidences were observed for the most frequently sprayed treatments (i.e. nine and 14 applications; treatments 3 and 2, respectively), while treatments with less spray applications resulted in higher dead flower bud incidences. Spray applications shortly before bloom (treatments 7 and 8 ) had little to no effect on dead flower buds incidence.

Assessments before bloom revealed 4 to $64 \%$ of the dormant flower buds carried Alternaria spp. infections (Fig. 7). The lowest infection rates were observed in the most frequently sprayed treatments (9-14 spray applications; treatments 3 and 2, respectively), while less spray applications resulted in higher infection rates. The infection rates of dormant flower buds that were sprayed shortly before bloom (treatments 7 and 8) were comparable to the untreated control, conforming that spraying shortly before bloom is not effective.

A strong correlation between the treatment, infection rate of flower buds with Alternaria spp. and the occurrence of dead flower buds was observed, indicating that control of Alternaria spp. reduced dead flower buds incidences significantly (Fig. 8).

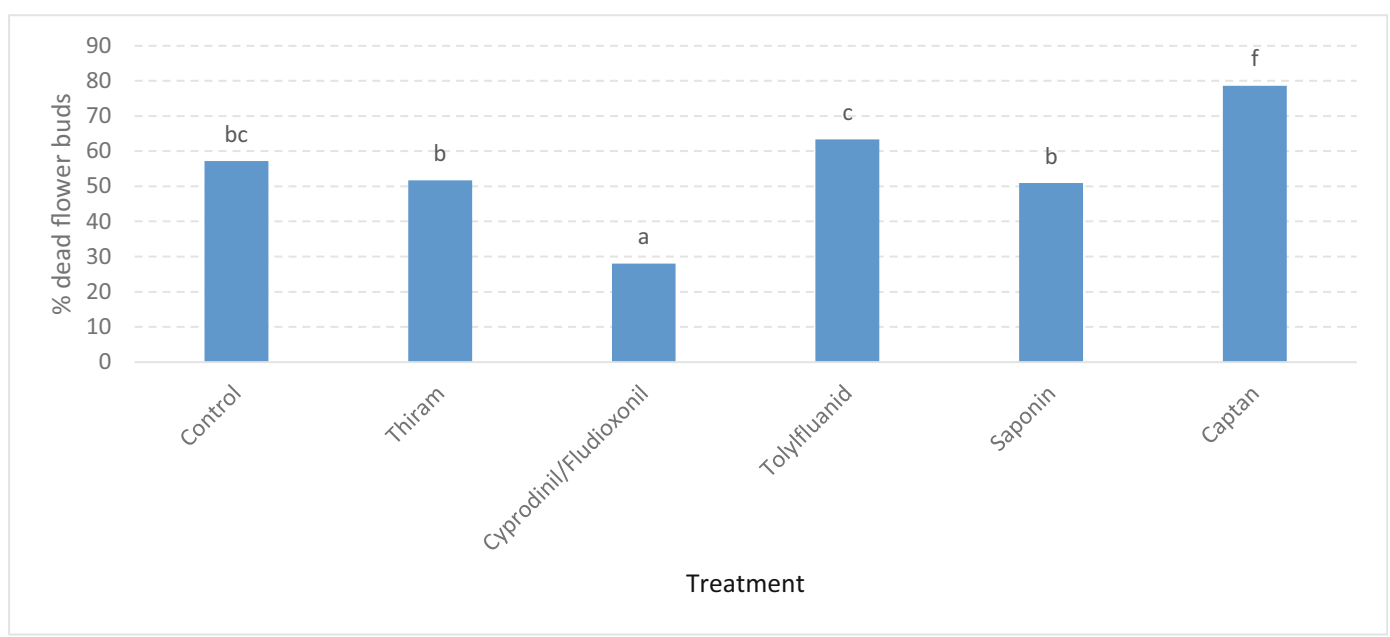

Fig. 6 Efficacy of different products to control dead dormant flower bud incidences. Different letter labels indicate significant differences $(P=0.05)$ 
Fig. 7 Efficacy of treatments against Alternaria spp. infections and the occurrence of dead dormant flower buds. Different letter labels indicate significant differences $(P=0.05)$. T1 to T8 are treatment numbers; see Materials and methods - Timing of application

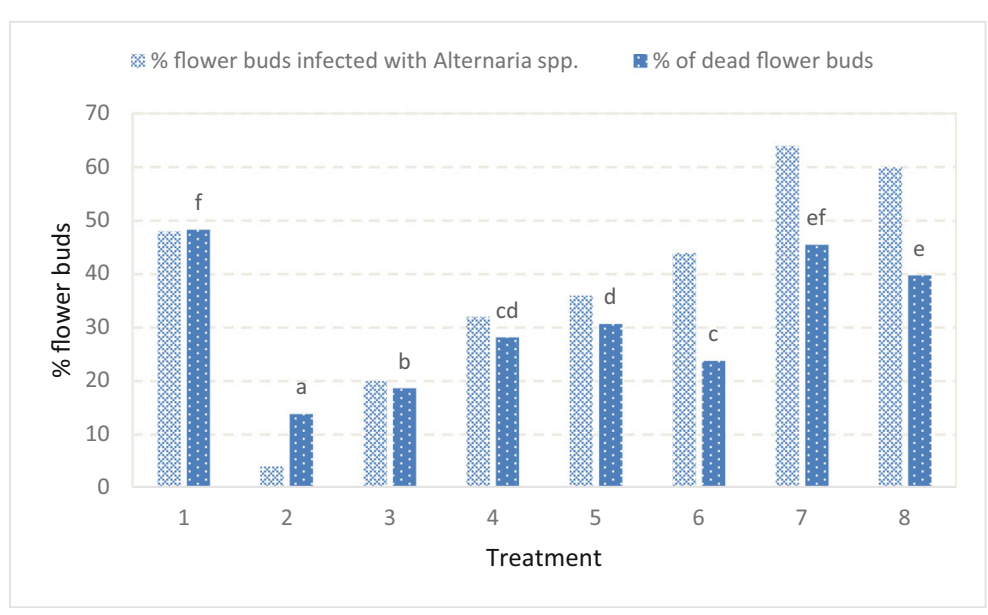

\section{Discussion}

Dead flower bud disease of pear is a phenomenon of economic importance in the major 'Conference' pear production areas of Europe (Deckers et al. 2008; Montesinos and Vilardell 1991, 2001). Especially in years with low bud numbers per tree, the disease causes significant (financial) losses due to low harvests. Thus far, the cause of dead flower buds disease remains unknown. Several causes have been proposed including insufficient tree chilling, unmet dormancy requirements, incompatibility between scion and cultivar, and various biotic stress agents such as pathogens and pests (Montesinos and Vilardell 2001).

In this study it was tested whether insufficient reduction of tree growth leads to increase dead flower buds incidences. Therefore various treatments to control tree growth were carried out. However, we did not find any indication that growth regulation can prevent the occurrence of dead flower buds. In contrast, several of the treatments led to increased dead flower bud incidences, such as Regalis application in 2004 and 2005, and root pruning in 2004. Thus, tree growth control is not suitable for reducing dead flower buds incidence on pear.

To provide evidence for the hypothesis that microbial pathogens may be involved in dead flower bud disease, potassium phosphate (Resistim) applications were tested. Potassium phosphate is a phosphonate derivative that is based on phosphorous acid and that affects plant production and productivity, but can also act as a biocide (GómezMerino and Trejo-Téllez 2015). More specifically, phosphite can be used for chemical control of various species of pathogenic bacteria, fungi and oomycetes (Amiri and Bompeix 2010; Burra et al. 2014; Groves et al. 2015; Lobato et al. 2008, 2011; Silva et al. 2011; Yogev et al. 2006). Thus, the observation that potassium phosphate
Fig. 8 Correlation between infection rate with Alternaria spp. and dead flower buds. T1 to T8 are treatment numbers; see Materials and methods - Timing of application

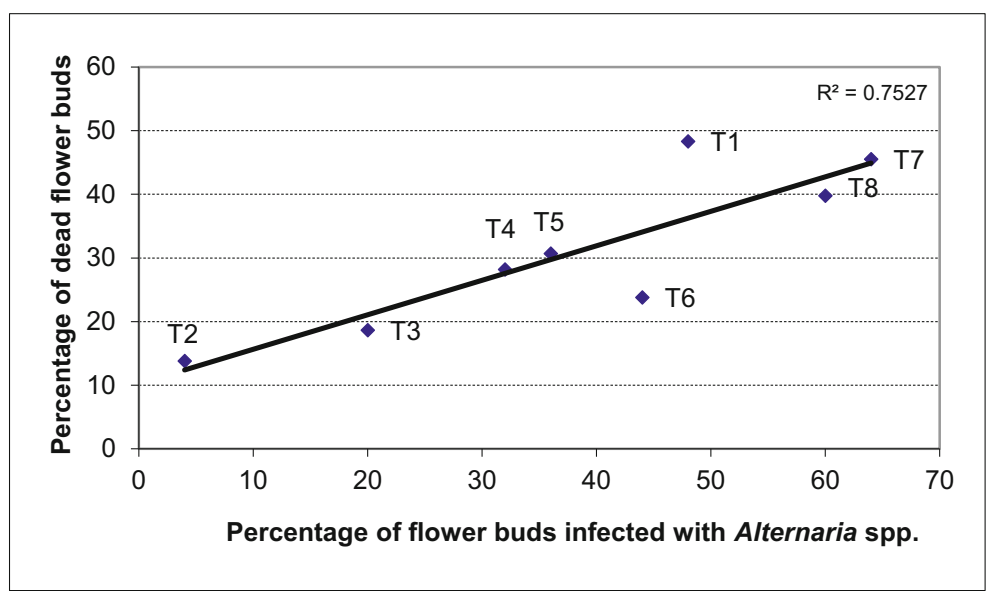


reduced the occurrence of dead flower buds on young twigs and dead terminal buds suggests an involvement of bacterial or fungal pathogens in the occurrence of dead flower buds of pears.

For many years it was commonly believed that the bacterium Pseudomonas syringae pv. syringae may be the causal agent of dead flower buds of pear (Montesinos and Vilardell 1987). This was partly due to the fact that P. syringae pv. syringae was proven to be the causal agent of blossom blast (Mansvelt and Hattingh 1986; Whitesides and Spotts 1991), the symptoms of which are characterized by blast of blossom and leaves in periods of cool wet weather during bloom and post-bloom stages (Jones and Aldwinckle 1990). However, blossom blast symptoms differ from the symptoms of dead flower bud disease as the latter is characterized by partial or complete necrosis of flower buds during dormancy or bud break as confirmed by our research.

P. syringae pv. syringae and associated ice nucleation active bacteria have been related to symptom development of blast of dormant flower buds in cold years, and Koch's postulates have been performed to demonstrate its involvement as causal agent (Montesinos and Vilardell 1987, 1991). However, extensive follow-up research in Spain did not reveal a significant relation between dead flower bud incidences and Pseudomonas levels (Montesinos and Vilardell 2001). Also, antibacterial treatments (copper and kasugamycin) did not affect the occurrence of dead flower buds (Montesinos and Vilardell 2001). Finally, also in our study a clear correlation between P. syringae pv. syringae colonization and dead flower buds occurrence could not be established. Collectively, these findings argue that P. syringae pv. syringae is not the causal agent of dead flower buds disease in the Netherlands, although the bacteria may be present as epiphyte and even as endophyte on and in flower buds.

In our research, Alternaria spp. were consistently found in diseased flower buds, and also frequently in asymptomatic flower buds. Moreover, strong correlations between dead dormant flower buds and infection rates of flower buds with Alternaria spp. were observed. From some affected flower buds no Alternaria spp. or other fungi were isolated, possibly due to a stringed disinfection. Surveys in commercial pear orchards in the Netherlands revealed high incidences of dead flower buds (up to $80 \%$ ) in certain years, that correlated with high infection rates (up to $100 \%$ ) of dormant flower buds with Alternaria spp.. Apparently, Alternaria spp. are capable of penetrating flower buds during the growing season, and during winter these infections result in necrotic flower tissues and dead flower buds in spring. Specific Alternaria fungicides could control dead flower buds significantly. General fungicides were not effective in controlling this disease.

The isolated Alternaria species were identified as A. arborescens SC and A. alternata SC and in laboratory tests the pathogenicity of $A$. alternata $\mathrm{SC}$ was proven on flower buds of detached pear twigs, while pathogenicity of $A$. arborescens $\mathrm{SC}$ on pear flower buds has still be proven. These results confirm Alternaria spp. as causal agents of dead flower buds of pear. Further research is needed to understand the infection process and pathogenicity of the different Alternaria species related to dead flower buds.

The genus Alternaria encompasses both nonpathogenic and pathogenic species. Although most Alternaria species are saprophytes (Thomma 2003), the genus also harbors well known (opportunistic) plant pathogens that cause a range of diseases on cereals, ornamentals, vegetables and fruits (Basim et al. 2017; Thomma 2003). Alternaria alternata is known to cause late blight in pistachio (Pryor and Michailides 2002; Evans et al. 1999) and several diseases in fruit crops such as moldy-core in apple (Reuveni et al. 2002), and brown rot in citrus (Timmer et al. 1998). Interestingly, Alternaria alternata was recently identified as the causal agent of bud and blossom blight in olive (Olea europaea) trees (Lagogianni et al. 2017).

Multiple Alternaria species have been implicated to cause leaf blotch and fruit spot of apple in many parts of the world (Filajdic and Sutton 1991; Gur et al. 2017; Harteveld et al. 2013; Rotondo et al. 2012). In Australia, four species groups were found to be associated with these diseases, including the Alternaria arborescens, Alternaria tenuissima/Alternaria mali, Alternaria alternata/A. tenuissima intermediate and Alternaria longipes species groups (Harteveld et al. 2013). Three Alternaria species groups were similarly proposed to cause the diseases in Italy, including A. arborescens, A. alternata and A. tenuissima (Rotondo et al. 2012). To date, however, fruit spot of apple caused by Alternaria spp. has not been reported in the Netherlands.

Pathogenicity of Alternaria spp. is often correlated with toxin production. Alternaria alternata includes both saprophytic and pathogenic isolates. Some isolates are known to produce host-specific toxins (HSTs) and are pathogenic to specific hosts, including apple, as well 
as European and Japanese pears (Tsuge et al. 2012). Other isolates produce non-HSTs and cause cell damage to several hosts of different genera (Meena et al. 2016). However, the involvement of toxins or enzymes produced by Alternaria spp. in the pathogenicity of dead flower buds of pear has to be determined.

In our analyses we identified A. arborescens SC and A. alternata $\mathrm{SC}$ as pathogens that may cause leaf spots on apple and pear in the Netherlands. Presumably, these Alternaria species are cross pathogenic and both capable in causing dead flower buds of pear. These findings are supported by studies by Harteveld et al. (2014) and Rotondo et al. (2012) that concluded that pathogenicity on apple is not an exclusive character of a specific Alternaria species group but is acquired by isolates independently.

Upon identifying Alternaria spp. as the causal agent of dead flower bud disease of pear, an effective fungicide based control strategy was developed. The choice of fungicides is important for achieving appropriate control of dead flower bud disease. It was previously noted that cultural measures may help to control Alternaria brown spot in citrus, but fungicide applications are essential to produce blemish free fruit (Timmer et al. 2000). Nevertheless, attempts to control Alternaria and moldy-core in apple by using foliar sprays of several fungicides, including benomyl, captan, dodine, mancozeb or some of their combinations, have been unsuccessful in the past, probably due to low efficacy (Reuveni 2006). Our experiments similarly showed that a number of standard fungicides, such as thiram, tolylfluanid and captan, were not effective in controlling dead flower buds disease. Moreover, the captan applications even appeared to increase disease incidence. Possibly, this fungicide affects antagonistic fungi of Alternaria spp., leading to improved conditions for massive growth of Alternaria spp. on pear buds. In contrast, spray applications with iprodione (Rovral) and a combination of cyprodinil and fludioxonil (Switch) reduced Alternaria spp. infections and the occurrence of dead flower buds significantly if they were applied during the (summer) growing season as spraying shortly before bloom was not effective. However, multiple sprays of fungicides with specific modes of action (e.g. iprodione) may lead to fungicide resistance development (Weber 2011). Therefore, alternated use of fungicides with different modes of action should be advised.

In conclusion, dead flower buds of pear in the Netherlands should be regarded as a fungal disease caused by A. alternata SC and potentially also
A. arborescens SC which may be controlled by specific fungicide applications.

Acknowledgements The authors wish to thank Peter Frans de Jong, Jacques Withagen, Ron Anbergen, Marian van Dieren and Nina Joosten for their excellent co-operation in this research.

Compliance with ethical standards This research was funded by the Dutch Product Board for Horticulture.

Conflict of interest The authors declare that no known conflicts of interests exists.

Human and animal studies This article does not contain any studies with human participation or animals performed by any of the authors.

Open Access This article is distributed under the terms of the Creative Commons Attribution 4.0 International License (http:// creativecommons.org/licenses/by/4.0/), which permits unrestricted use, distribution, and reproduction in any medium, provided you give appropriate credit to the original author(s) and the source, provide a link to the Creative Commons license, and indicate if changes were made.

\section{References}

Amiri, A., \& Bompeix, G. (2010). Control of Penicillium expansum with potassium phosphite and heat treatment. Crop Protection, 30, 222-227.

Arruda, J. J. P., \& Camelatto, D. (1999). Abortamento de gemas florais de cinco cultivares de pereira (Pyrus spp., L.) em dois locais do Rio Grande do Sul, Brasil. Ciência Rural, 29, 635638.

Basim, E., Basim, H., Abdulai, M., Baki, D., \& Öztürk, N. (2017). Identification and characterization of Alternaria alternata causing leaf spot of olive tree (Olea europaea) in Turkey. Crop Protection, 92, 79-88.

Burra, D. D., Berkowitz, O., Hedley, P. E., Morris, J., Resjö, S., Levander, F., Liljeroth, E., Andreasson, E., \& Alexandersson, E. (2014). Phosphite-induced changes of the transcriptome and secretome in Solanum tuberosum leading to resistance against Phytophthora infestans. BMC Plant Biology, 14, 254.

Deckers, T., \& Schoofs, H. (2001). Bacterial problems in Belgian pear growing. The Compact Fruit Tree, 34, 121-124.

Deckers, T., Schoofs, H., Creemers, P., Latorse, M. P., Rosati, D., \& De Maeyer, L. (2008). Dead flower buds on 'Conference' pear trees: proposal of a solution. Acta Horticulturae, 800, 847-855.

Evans, N., Michailides, T. J., Morgan, D., \& Felts, D. (1999). Studies on sources of inoculum of Alternaria late blight of pistachio. KAC Plant Protection Quarterly, 9, 4-6.

Faust, M., Erez, A., Rowland, L. J., Wang, S. Y., \& Norman, H. A. (1997). Bud dormancy in perennial fruit trees: physiological 
basis for dormancy induction, maintenance, and release. HortScience, 32, 623-629.

Filajdic, N., \& Sutton, T. B. (1991). Identification and distribution of Alternaria mali on apples in North Carolina and susceptibility of different varieties of apples to Alternaria blotch. Plant Disease, 75, 1045-1048.

Gómez-Merino, F. C., \& Trejo-Téllez, L. I. (2015). Biostimulant activity of phosphite in horticulture. Scientia Horticulturae, 196, 82-90.

Groves, E., Howard, K., Hardy, G., \& Burgess, T. (2015). Role of salicylic acid in phosphite induced protection against Oomycetes; a Phytophthora cinnamomi-Lupinus augustifolius model system. European Journal of Plant Pathology, 141, 559-569.

Gur, L., Reuveni, M., \& Cohen, Y. (2017). Occurrence and etiology of Alternaria leaf blotch and fruit spot of apple caused by Alternaria alternata f. sp. mali on cv. Pink Lady in Israel. European Journal of Plant Pathology, 147, 695-708.

Harteveld, D. O. C., Akinsanmi, O. A., \& Drenth, A. (2013). Multiple Alternaria species groups are associated with leaf blotch and fruit spot diseases of apple in Australia. Plant Pathology, 62, 289-297.

Harteveld, D. O. C., Akinsanmi, O. A., \& Drenth, A. (2014). Pathogenic variation of Alternaria species associated with leaf blotch and fruit spot of apple in Australia. European Journal of Plant Pathology, 139, 789-799.

Janse, J. D. (1991). Pathovar discrimination within Pseudomonas syringae subsp. savastanoi using whole cell fatty acid analysis and pathogenicity as criteria. Systematic and Applied Microbiology, 14, 79-84.

Jones, A. L., \& Aldwinckle, H. S. (1990). Compendium of apple and pear diseases. St Paul: APS Press.

King, E. D., Ward, M. K., \& Raney, D. E. (1954). Two simple media for the demonstration of pyocyanin and fluorescin. Journal of Laboratory and Clinical Medicine, 44, 301-317.

Lagogianni, C. S., Tjamos, E. C., Antoniou, P. P., \& Tsitsigiannis, D. I. (2017). First report of Alternaria alternata as the causal agent of Alternaria bud and blossom blight of Olives. Plant Disease, 101, 2151.

Lelliott, R. A., \& Stead, D. E. (1987). Methods for the diagnosis of bacterial diseases of plants (Vol. 2). Oxford: Blackwell Publishing Ltd/ British Society for Plant Pathology.

Lobato, M. C., Olivieri, F. P., González Altamiranda, E. A., Wolski, E. A., Daleo, G. R., Caldiz, D. O., \& Andreu, A. B. (2008). Phosphite compounds reduce disease severity in potato seed tubers and foliage. European Journal of Plant Pathology, 122, 349-358.

Lobato, M. C., Machinandiarena, M. F., Tambascio, C., Dosio, G. A. A., Caldiz, D. O., Daleo, G. R., Andreu, A. B., \& Olivieri, F. P. (2011). Effect of foliar applications of phosphite on post harvest potato tubers. European Journal of Plant Pathology, 130, 155-163.

Maas, F. M. (2005). Shoot growth, fruit production and return bloom in 'Conference' and 'Doyenné du Comice' treated with Regalis (prohexadione-calcium). Acta Horticulturae, $671,517-524$.

Maas, F. (2008). Strategies to control tree vigour and optimise fruit production in 'Conference' pears. Acta Horticulturae, 800, 139-146.
Mansvelt, E. L., \& Hattingh, M. J. (1986). Pear blossom blast in South Africa caused by Pseudomonas syringae pv. syringae. Plant Pathology, 35, 337-343.

Marafon, A. C., Herter, F. G., Hawerroth, F. J., \& Silva, A. S. (2010). Occurrence time and intensity of flower bud necrosis and inflorescence duplication in pear trees 'Housui' (Pyrus pyrifolia (Burm.) Nak.) during the dormancy period in Pelotas - RS, Brazil. Acta Horticulturae, 872, 97-100.

Meena, M., Gupta, S. K., Swapnil, P., Zehra, A., Dubey, M. K., \& Upadhyay, R. S. (2016). Alternaria toxins: potential virulence factors and genes related to pathogenesis. Frontiers in Microbiology, 8, 1451.

Mohan, S. K., \& Schaad, N. W. (1987). An improved agar plating assay for detecting Pseudomonas syringae pv. syringae and P. s. pv. phaseolicola in contaminated bean seed. Phytopathology, 77, 1390-1395.

Montesinos, E., \& Vilardell, P. (1987). On the role of Pseudomonas syringae pv. syringae in blast of pear trees in Catalunya, Spain. Acta Horticulturae, 256, 143-151.

Montesinos, E., \& Vilardell, P. (1991). Relationship among population levels of Pseudomonas syringae, amount of ice nuclei, and incidence of blast on dormant flower buds in commercial pear orchards in Cataluna, Spain. Phytopathology, 81, 113-119.

Montesinos, E., \& Vilardell, P. (2001). Effect of bactericides, phoshonates and nutrient amendments on blast of dormant flower buds of pear: a field evaluation for disease control. European Journal of Plant Pathology, 107, 787-794.

Nakasu, B. H., Herter, F. G., Leite, D. L., \& Raseira, M. C. B. (1995). Pear flower bud abortion in Southern Brazil. Acta Horticulturae, 395, 185-192.

Naor, A., Flaishman, M., Stern, R., \& Erez, A. (2003). Temperature effects on dormancy completion of vegetative buds in apple. Journal of the American Society for Horticultural Science, 128, 636-641.

Pryor, B. M., \& Michailides, T. J. (2002). Morphological, pathogenic, and molecular characterization of Alternaria isolates with Alternaria late blight of pistachio. Phytopathology, 92, 406-416.

Qiu, W., Huai, Y., Xu, F., Xu, L., Xie, G., Li, B., Yu, S., \& Liu, J. (2008). Pear blossom blast caused by Pseudomonas syringae pv. syringae in China. Agricultural Sciences in China, 7, 1091-1096.

Reuveni, M. (2006). Inhibition of germination and growth of Alternaria alternata and mouldy-core development in red delicious apple fruit by Bromuconazole and Sygnum. Crop Protection, 25, 253-258.

Reuveni, M., Sheglov, D., Sheglov, N., Ben-Arie, R., \& Prusky, D. (2002). Sensitivity of Red Delicious apple fruit at various phenologic stages to infection by Alternaria alternata and moldy-core control. European Journal of Plant Pathology, 108, 421-427.

Rodrigo, J. (2000). Spring frosts in deciduous fruit trees - morphological damage and flower hardiness. Scientia Horticulturae, 85, 155-173.

Rotondo, F., Collina, M., Brunelli, A., \& Pryor, B. M. (2012). Comparison of Alternaria spp. collected in Italy from apple with A. mali and other AM-toxin producing strains. Phytopathology, 102, 1130-1142. 
Silva, O. C., Santos, H. A. A., Dalla Pria, M., \& May-De Mio, L. L. (2011). Potassium phosphite for control of downy mildew of soybean. Crop Protection, 30, 598-604.

Simmons, E. G. (2007). Alternaria. An identification manual. In: CBS biodiversity series 6. CBS Fungal Biodiversity Centre, Utrecht, The Netherlands.

Stushnoff, C., Fowler, D. B., \& Brule-Babel, A. (1984). Breeding and selection for resistance to low temperature. In P. B. Vose (Ed.), Plant breeding - A contemporary basis (pp. 115-136). Oxford: Pergamon Press.

Thomma, B. (2003). Alternaria spp.: from general saprophyte to specific parasite. Molecular Plant Pathology, 4, 225-236.

Timmer, L. W., Solel, Z., Gottwald, T. R., Ibanez, A. M., \& Zitko, S. E. (1998). Environmental factors affecting production, release, and field populations of conidia of Alternaria alternata, the cause of brown spot of citrus. Phytopathology, 88, 1218-1223.

Timmer, L. W., Darhower, H. M., Zitko, S. E., Peever, T. L., Ibanez, A. M., \& Bushong, P. M. (2000). Environmental factors affecting the severity of Alternaria brown spot of citrus and their potential use in timing fungicide applications. Plant Disease, 84, 638-643.

Tsuge, T., Harimoto, Y., Akimitsu, K., Ohtani, K., Kodama, M., Akagi, Y., Egusa, M., Yamamoto, M., \& Otani, H. (2012). Host selective toxins produced by the plant pathogenic fungus Alternaria alternata. FEMS Microbiology Reviews, 37, $44-46$.

Verissimo, V., Herter, F. G., Rodrigues, A. C., Gardin, J. P., \& Silva, J. B. (2004). Caracterização de gemas florais de pereira (Pyrus sp.) relacionada ao abortamento floral. Revista Brasileira de Fruticultura, 26, 193-197.

Weber, R. W. S. (2011). Resistance of Botrytis cinerea to multiple fungicides in Northern German small-fruit production. Plant Disease, 95, 1263-1269.
Wenneker, M., Heijne, B., Tjou-Tam-Sin, L. T., Van Bruggen, A. S., \& Vink, P. (2004). Dead flower buds of pear: effect of tree growth control, and Alternaria alternata as causal agent. Communications in Agricultural and Applied Biological Sciences, 69, 415-420.

Wenneker, M., Tjou-Tam-Sin, L. T., Van Bruggen, A. S., \& Vink, P. (2006). Alternaria alternata, causal agent of dead (dormant) flower bud disease of pear. IOBC-WPRS Bulletin, 29, 265-270.

Wenneker, M., Khanh, K. T. K., Woudenberg, J. H. C., \& Thomma, B. P. H. J. (2018). First report of Alternaria arborescens species complex causing leaf blotch and associated premature leaf drop of 'Golden delicious' apple trees in the Netherlands. Plant Disease, 102, 1654.

Whitesides, S. K., \& Spotts, R. A. (1991). Induction of pear blossom blast caused by Pseudomonas syringae pv. syringae. Plant Pathology, 40, 118-127.

Woudenberg, J. H. C., Groenewald, J. Z., Binder, M., \& Crous, P. W. (2013). Alternaria redefined. Studies in Mycology, 75, 171-212.

Woudenberg, J. H. C., Seidi, M. F., Groenewald, J. Z., de Vries, M., Stielow, J. B., Thomma, B. P. H. J., \& Crous, P. W. (2015). Alternaria section Alternaria: Species, formae speciales or pathotypes? Studies in Mycology, 82, 1-21.

Yamamoto, R. R., Katsumi-Horigane, A., Yoshida, M., Sekozawa, Y., Sugaya, S., \& Gemma, H. (2010). "Floral primordia necrosis" incidence in mixed buds of Japanese pear (Pyrus pyrifolia (Burm.) Nakai var. culta) 'Housui' grown under mild winter conditions and the possible relation with water dynamics. Journal of the Japanese Society for Horticultural Science, 79, 246-257.

Yogev, E., Sadowsky, A., Solel, Z., Oren, Y., \& Orbach, Y. (2006). The performance of potassium phosphite for controlling Alternaria brown spot of citrus fruit. Journal of Plant Diseases and Protection, 113, 207-213. 